Sains Malaysiana 49(10)(2020): 2499-2506

http://dx.doi.org/10.17576/jsm-2020-4910-15

\title{
Hibiscus sabdariffa Linn. (Roselle) Polyphenols-Rich Extract Prevents Hyperglycemia-Induced Cardiac Oxidative Stress and Mitochondrial Damage in Diabetic Rats
}

(Ekstrak Kaya-Polifenol Hibiscus sabdariffa Linn. (Roselle) Mencegah Tekanan Oksidatif dan Kerosakan Mitokondria Jantung Aruhan Hiperglisemia pada Tikus Diabetes)

\author{
Nur Liyana Mohammed Yusof, Tengku Nurul Tasnim Tengku AfFendi, Fatin Farhana Jubaidi, Satirah \\ ZAINAL ABIDIN \& SiTI BALKIS BUDIN*
}

\begin{abstract}
Cardiac mitochondrial damage plays a crucial role in the initiation of diabetic cardiomyopathy. Hibiscus sabdariffa Linn. (roselle) has been proven to prevent various pathological conditions, however it remains unclear whether roselle extract can attenuate diabetes-induced mitochondrial damage. This study aimed to investigate whether roselle polyphenol-rich extract (HPE) is able to ameliorate hyperglycemia-induced oxidative stress and mitochondrial damage in diabetic rats. Diabetes was induced by a single dose of streptozotocin (55 $\mathrm{mg} \mathrm{kg}^{-1}$, intraperitoneally); and diabetic rats were then orally fed with $100 \mathrm{mg} \mathrm{kg}^{-1}$ of HPE (DM+Roselle) or $150 \mathrm{mg} \mathrm{kg}^{-1}$ of Metformin (DM+MET) daily for 4 weeks. Meanwhile, the control and untreated diabetic (DM) groups were only orally given normal saline. After 4 weeks of treatment, the results showed that DM+Roselle group significantly improved blood glucose level and lipid profile status $(p<0.05)$ compared to the DM group. DM+Roselle group also had significantly $(p<0.05)$ lower the level of thiobarbituric acid reactive substances (TBARS) and advanced oxidation protein product (AOPP) in cardiac homogenate than the DM group. HPE supplementation also significantly improved activities of total superoxide dismutase (SOD), SOD-2, catalase (CAT) and level of reduced glutathione (GSH) of the cardiac homogenate. Complex I activity of mitochondria respiratory chain also decreased significantly $(p<0.05)$ in DM+Roselle group as compared to the DM group. Observations using electron microscope showed that mitochondria in the DM+Roselle group appeared more organized compared to the DM group. In conclusion, these results highlight the potential of HPE as a protective agent against oxidative stress and mitochondrial damage in diabetic condition.
\end{abstract}

Keywords: Hyperglycemia; mitochondria; myocardial damage; ROS; roselle

\section{ABSTRAK}

Kerosakan mitokondria jantung memainkan peranan yang penting dalam permulaan kardiomiopati diabetis. Walaupun Hibiscus sabdariffa Linn. (rosel) terbukti berupaya mencegah pelbagai keadaan patologi, keupayaan ekstrak rosel dalam memulihkan kerosakan mitokondria aruhan diabetis melitus masih lagi belum diketahui. Kajian ini mengkaji sama ada ekstrak rosel kaya polifenol (HPE) mampu mencegah tekanan oksidatif dan kerosakan aruhan hiperglisemia pada tikus diabetis. Diabetis diaruh dengan suntikan tunggal streptozotosin (55 $\mathrm{mg} \mathrm{kg}^{-1}$, intraperitonial); dan tikus diabetis kemudiannya diberi $100 \mathrm{mg} \mathrm{kg}^{-1} \mathrm{HPE}$ (DM+Roselle) atau $150 \mathrm{mg} \mathrm{kg}^{-1}$ Metformin (DM+MET) setiap hari selama 4 minggu. Tikus kawalan normal (NDM) dan diabetis tanpa rawatan (DM) hanya diberikan salin normal. Selepas 4 minggu suplementasi, hasil kajian menunjukkan kumpulan DM+Roselle mempunyai aras glukosa darah dan status profil lipid yang lebih baik secara signifikan $(p<0.05)$ berbanding kumpulan DM. Kumpulan DM+Roselle juga turut menunjukkan aras bahan reaktif asid tiobarbiturik (TBARS) dan produk oksidasi protein lanjutan (AOPP) homogenat jantung yang lebih rendah $(p<0.05)$ berbanding kumpulan DM. Suplementasi HPE turut membaik pulih aktiviti jumlah superoksida dismutase (SOD), SOD-2, katalase (CAT) dan aras glutation terturun (GSH) pada homogenat jantung tikus. Aktiviti Kompleks I pada rantaian pernafasan mitokondria turut menurun dengan ketara pada kumpulan DM+Roselle berbanding kumpulan DM. Pemerhatian dengan mikroskop elektron menunjukkan mitokondria pada jantung tikus kumpulan DM+Roselle kelihatan lebih teratur berbanding kumpulan DM. Kesimpulannya, hasil kajian ini mencadangkan potensi HPE sebagai agen perlindungan tekanan oksidatif serta mencegah kerosakan mitokondria dalam keadaan diabetis.

Kata kunci: Hiperglisemia; kecederaan mitokondria; mitokondria; ROS; rosel 


\section{INTRODUCTION}

Cardiovascular diseases (CVD) continue to rise in incidence and have substantially contributed to the highest rate of morbidity and mortality among diabetic patients. Diabetes is a significant risk factor for myocardial infarction, stroke and heart failure (Li \& Aronow 2011). Hyperglycaemia plays an important role in the initiation of cardiovascular diseases in diabetic patients by promoting the increase of oxidative stress and mitochondrial damage (Gomes 2013; Madsen-Bouterse et al. 2010; Vanessa Fiorentino et al. 2013).

Hyperglycemia-induced reactive oxygen species (ROS) accumulation occurs through several metabolic pathways, including the polyol pathway, hexosamine biosynthesis pathway, formation of advanced glycation end products (AGE)s, activation of protein kinase $\mathrm{C}$ isoforms, as well as perturbed antioxidant defense system (Brownlee 2001). ROS overproduction leads to oxidative damage and has been implicated in the pathophysiology of various diabetic complications (Budin et al. 2019, 2018). It is also commonly suggested that impairment in cardiac antioxidant system due to overwhelming ROS production mediates majority of microvascular and macrovascular diabetic complications (Vanessa Fiorentino et al. 2013). Manganese superoxide dismutase (MnSOD) or also known as superoxide dismutase-2 (SOD-2) plays an important role in inhibiting cellular oxidative damage by preventing accumulation of superoxide and facilitating the conversion of superoxide to $\mathrm{H}_{2} \mathrm{O}_{2}$ (Huynh et al. 2014). Regulation of superoxide radicals by overexpression of SOD-2 has been shown to prevent cardiomyocyte apoptosis (Dai et al. 2011). Oxidative stress and cardiac dysfunction are closely linked to metabolic abnormalities and mitochondria damage in the cardiomyocytes considering cardiac muscle is enriched with mitochondria for production of energy that sustains cardiac contraction and cardiac metabolism (Duncan 2011). Hyperglycemia may also regulate mitochondrial DNA damage, which results in eventual reduction in the expression of mitochondrial-encoded genes critical for the formation of Complex I and Complex III in the electron transport chain (Madsen-Bouterse et al. 2010).

Use of dietary antioxidants from natural products reduces oxidative stress and slows down progression of diabetic cardiovascular complications (Hussan et al. 2015). Polyphenols which are natural compounds found in fruits, vegetables, cereals, and beverages have been shown to elicit various health benefits (Matough et al. 2012). Hibiscus sabdariffa Linn. (roselle) is a local plant enriched with polyphenols such as protocathecuic acid, cathecins, caffeic acid and epigallocathechin-gallate (Lim et al. 2017). Recently, roselle has gained broad attention for its potential in alleviating cardiovascular problems such as atherosclerosis (Chen et al. 2003), hypertension
(Si et al. 2017a), and dyslipidemia (Yusof et al. 2017). Roselle polyphenols also lowers blood glucose (Yusof et al. 2018) and prevents vascular complications by inhibiting migration of vascular endothelial cells (Zainalabidin et al. 2018).

In regard to the potentials of roselle polyphenols in eliminating various cardiovascular abnormalities, therefore in this present study, we examined the potential effects of roselle polyphenol-rich extract (HPE) in ameliorating hyperglycemia-induced cardiac oxidative stress and mitochondrial damage in type- 1 diabetic rats.

\section{MATERIALS AND METHODS}

\section{EXTRACTION OF ROSELLE}

Dried roselle calyces were supplied by Ai Agro Marketing, Terengganu, Malaysia around July 2018. HPE extraction was done as described previously by Yusof et al. (2017). In brief, $50 \mathrm{~g}$ of dried roselle powder was mixed with methanol and was stirred for $30 \mathrm{~min}$ at 60 ${ }^{\circ} \mathrm{C}$. The extract was then filtered and evaporated using rotary evaporator $\left(\leq 5^{\circ} \mathrm{C}, 20 \mathrm{mbar}\right)$. Dried residue was solubilized in deionized water $(\mathrm{pH} 2.3)$ and the extract solution was then partitioned with hexane and ethyl acetate. Ethyl acetate soluble fraction was evaporated till dryness and the final product of HPE was stored at $-40{ }^{\circ} \mathrm{C}$ before further use to preserve the polyphenol content (Srivastava et al. 2007). HPE solution was freshly prepared every day for rat treatment according to the dose given.

\section{ANIMALS}

Twenty-four male Sprague Dawley rats (250-300 g) were obtained from the Animal Unit, Faculty of Medicine, Universiti Kebangsaan Malaysia. These rats were housed in a proper ventilated room with equal hours of light/dark cycle in plastic cages covered with wood shaving and were provided access to rodent pellet and water ad libitum. All rats were acclimatized to the research laboratory for 7 days prior to initiation of the experiments. This experimental design has been approved by Animal Ethic Committee of Universiti Kebangsaan Malaysia (Ethic code: FSK2015/2014/BALKIS/11-FEB./643-FEB.-2015FEB-2018).

\section{INDUCTION OF DIABETES IN RATS}

After an overnight fasting, diabetes was induced via a single dose of freshly prepared streptozotocin (STZ) (Sigma Chemicals, ST. Louis, Missouri, USA) (55 $\mathrm{mg} \mathrm{kg}^{-1}$, intraperitoneal) in $0.9 \%$ normal saline. After 3 days, rats with fasting blood glucose level exceeding $15.0 \mathrm{mmol}$ $\mathrm{L}^{-1}$ were selected for the study. The diabetic rats were divided into 3 groups each containing 6 rats; untreated diabetic group (DM), diabetic rats treated with HPE (DM+Roselle), and diabetic rats treated with Metformin 
(DM+MET). DM+Roselle and DM+MET group received HPE extract (100 mg kg-1) and Metformin $\left(100 \mathrm{mg} \mathrm{kg}^{-1}\right)$, respectively, for 4 weeks via force feeding. Non-diabetic rats acted as normal control group (NDM). NDM and DM group received $0.9 \%$ normal saline for the rest of the experimental period.

\section{SAMPLE COLLECTION AND PROCESSING}

After 4 weeks of supplementation, rats were fasted overnight and blood were collected under deep anesthesia. Hearts were excised, weighed and washed with cold 50 $\mathrm{mM}$ phosphate buffer solution ( $\mathrm{pH} 7.4)$. Part of the heart tissue was homogenized in $50 \mathrm{mM}$ phosphate buffer solution, centrifuged at $10000 \mathrm{x}$ g for $15 \mathrm{~min}$ at $4^{\circ} \mathrm{C}$, and the obtained supernatant was stored at $-40^{\circ}$ for oxidative stress and antioxidant evaluation. The whole procedure was conducted on ice. The other part of the heart tissue was used for isolation of mitochondria.

\section{ASSESSMENT OF OXIDATIVE STRESS AND ANTIOXIDANT STATUS}

Heart lipid peroxidation was estimated by the assessment of thiobarbituric reactive substances (TBARS) level as mentioned by Stocks and Dormandy (1971). Advanced oxidation protein product (AOPP) was measured according to method described by Witko-Sarsat et al. (1996). Total superoxide dismutase (SOD) activity was determined by measuring the inhibition of formazan formation (Beyer \& Fridovich 1987) while SOD-2 activity was measured in the presence of $5 \mathrm{mM}$ sodium cyanide to inhibit SOD-1 and SOD-3 activities. Reduced glutathione (GSH) level was measured according to Ellman (1959) and catalase activity was measured according to the method by Aebi (1984).

\section{ISOLATION OF MITOCHONDRIA}

Isolation of cardiac mitochondria was performed based on Iglesias-González et al. (2013). The cardiac tissue was cut, minced, and homogenized in ice cold isolation buffer. The homogenized cardiac tissue was then centrifuged at low speed $600 \times \mathrm{g}$ for $10 \mathrm{~min}$ twice and the supernatants were pooled together. The pooled supernatant was centrifuged at high speed $12,000 \times \mathrm{g}$ for 8 $\mathrm{min}$. The pellet was re-suspended in $10 \mathrm{~mL}$ isolation buffer and centrifuged at high speed $12,000 \times \mathrm{g}$ for $10 \mathrm{~min}$ twice. Final pellet was re-suspended in $150 \mu \mathrm{L}$ buffer without EDTA and was used for the analysis of mitochondrial Complex I and Complex III activities. All isolation procedure was performed on cold condition.

\section{MITOCHONDRIAL COMPLEX I AND COMPLEX III ACTIVITY IN CARDIAC TISSUE}

Mitochondrial respiratory activity of Complex I and Complex III activity were assessed using MitoCheck ${ }^{\circledR}$
Complex I and Complex III Activity Assay Kit (USA).

\section{TRANSMISSION ELECTRON MICROSCOPIC ANALYSIS}

Cardiac tissue $\left(1 \mathrm{~mm}^{3}\right.$ ) were fixed using $2 \%$ glutaraldehyde in $0.1 \mathrm{M}$ phosphate buffer $(\mathrm{pH} 7.4)$. The specimens were rinsed in phosphate buffer, post fixation in $1 \%$ osmic acid for $1 \mathrm{~h}$ at room temperature, and en bloc staining with uranyl acetate (Tandler 1990) followed by epoxy embedding (Polybed R812; Fluka). Thin sections were stained with uranyl acetate and lead citrate and examined in a CM12-Philips transmission electron microscope (Netherlands) equipped with a Mega-View-III digital camera and a Soft Imaging System (Germany) for a computerized acquisition of images. For quantitative assessments, mitochondrial size was analyzed using the batch mode of the ImageJ macro with 200 randomly chosen $(3000 \times$ and $1000 \times$ magnification of TEM) fields in each group (Nisoli et al. 2004).

\section{STATISTICAL ANALYSIS}

Data were expressed as mean \pm standard error of mean (SEM). Statistical significance was determined using one-way ANOVA followed by Post Hoc Turkey's test. Differences were considered statistically significant at $\mathrm{p}<0.05$.

\section{RESULTS AND DISCUSSION}

Roselle is increasingly used in traditional medicine and it is well reported as a dietary nutritional supplement to prevent hypertension ( $\mathrm{Si}$ et al. 2017b) and diabetes (Mohammed Yusof et al. 2018a; 2018b). Our previous study has identified various phenolic compounds in HPE such as anthocyanin (3-glucoside cyanidine, 3-O-glucosylrutinoside cyanidine), phenolic acid (chlorogenic acid, hibiscus acid) and flavonoid (quercetin, routine) (Lim et al. 2017). Study conducted by Ochani and D'Mello (2009) also showed that roselle calyx extract contains phenolic compounds and bioflavonoids such as anthocyanins, glycosides, protocatechuic acid and hibiscus acid.

The current study showed that there was a reduction in cardiac weight in all diabetic groups; however, this was not altered by both HPE and Metformin. Fasting plasma glucose level was found to be significantly higher in all diabetic groups $(p<0.05)$ and HPE supplementation successfully decreased glucose level compared to the untreated DM group $(\mathrm{p}<0.05)$. HPE also significantly lowered serum total cholesterol, triglyceride (TG), lowdensity lipoprotein (LDL) and increased high-density lipoprotein (HDL) and TG/HDL levels. Meanwhile, $\mathrm{DM}+\mathrm{MET}$ group also showed significant improvement in blood glucose and lipid profile $(\mathrm{p}<0.05)$ (Table 1). 
TABLE 1. Cardiac weight, blood glucose and blood lipid parameters in all experimental groups

\begin{tabular}{|c|c|c|c|c|}
\hline GROUP & NDM & DM & $\mathrm{DM}+$ Roselle & $\mathrm{DM}+\mathrm{MET}$ \\
\hline HW & $1.002 \pm 0.04$ & $0.56 \pm 0.02^{\mathrm{a}}$ & $0.70 \pm 0.03^{\mathrm{a}}$ & $0.60 \pm 0.03^{\mathrm{a}}$ \\
\hline Plasma glucose & $6.94 \pm 0.34$ & $27.48 \pm 1.23^{\mathrm{a}}$ & $17.02 \pm 0.96^{\mathrm{a}, \mathrm{b}}$ & $18.74 \pm 0.37^{\mathrm{a}, \mathrm{b}}$ \\
\hline $\mathrm{TC}$ & $2.41 \pm 0.16$ & $3.16 \pm 0.17^{\mathrm{a}}$ & $1.67 \pm 0.09^{\mathrm{a}, \mathrm{b}}$ & $1.50 \pm 0.05^{\mathrm{a}, \mathrm{b}}$ \\
\hline TG & $1.04 \pm 0.10$ & $2.86 \pm 0.06^{\mathrm{a}}$ & $2.24 \pm 0.15^{\mathrm{a}, \mathrm{b}}$ & $1.82 \pm 0.10^{\mathrm{a}, \mathrm{b}}$ \\
\hline LDL & $1.82 \pm 0.13$ & $2.15 \pm 0.16$ & $0.75 \pm 0.07^{\mathrm{b}}$ & $0.80 \pm 0.03^{\mathrm{a}, \mathrm{b}}$ \\
\hline HDL & $0.49 \pm 0.05$ & $0.39 \pm 0.01$ & $0.62 . \pm 0.05^{\mathrm{a}, \mathrm{b}}$ & $0.67 \pm 0.03^{\mathrm{a}, \mathrm{b}}$ \\
\hline TG/HDL & $2.21 \pm 0.28$ & $7.42 \pm 0.27^{\mathrm{a}}$ & $3.71 \pm 0.33^{\mathrm{a}, \mathrm{b}}$ & $2.77 \pm 0.25^{\mathrm{b}}$ \\
\hline
\end{tabular}

Note: Heart weight (HW) was expressed in gram whereas plasma glucose, total cholesterol (TC), triglyceride (TG), high-density lipoprotein (HDL) and low-density lipoprotein (LDL) were expressed in $\mathrm{mmol} / \mathrm{L}$. Values were expressed as the mean $\pm \mathrm{SEM}$ ( $\mathrm{n}=6$ per group), ${ }^{\mathrm{a}} \mathrm{p}<0.05 \mathrm{vs}$. NDM group, ${ }^{\mathrm{b}} \mathrm{p}<0.05 \mathrm{vs}$. DM

In diabetes, dyslipidemia plays a major role in the pathogenesis of cardiac dysfunction. Dyslipidemia leads to lipotoxicity, resulting in the changes in cardiac metabolism, morphology, and function (Liu et al. 2014) as well as triggering cardiomyocyte apoptosis (Lee \& Pervaiz 2007). Monitoring of cholesterol levels and TG/ HDL ratios is important as it is a factor in identifying and controlling the risk of chronic heart disease (Packer et al. 2017). Four weeks of HPE supplementation not only managed to reduce the level of TG (22\% reduction), TC ( $52 \%$ reduction), and LDL ( $35 \%$ reduction), TG/HDL ratio ( $50 \%$ reduction), but also increases HDL ( $37 \%$ increment) levels in DM+Roselle group when compared to untreated diabetic group. The results of this study are in line with the study conducted by Peng et al. (2011), which had found that HPE exerted antihyperlipidemic effects in type-2 diabetes mellitus mice models. In this study, HPE improves dyslipidemia in type-1 diabetes model which is also an important risk factor for diabetic-induced cardiovascular problems especially diabetic cardiomyopathy. Such action of roselle extract may be due to its ability to prevent the absorption of intestinal cholesterol, disrupt the production of lipoprotein and promote the removal of LDL in the blood by increasing the expression of LDL receptors in the liver (Ochani \& D'Mello 2009). Previously, data from our laboratory has reported the presence of hibiscus acid, chlorogenic acid, kaempferol, quercetin, and other polyphenols in HPE (Lim et al. 2017) which may exert antihyperlipidemic effect through their synergistic effect. Furthermore, hydroxycitric acid and hibiscus acid can
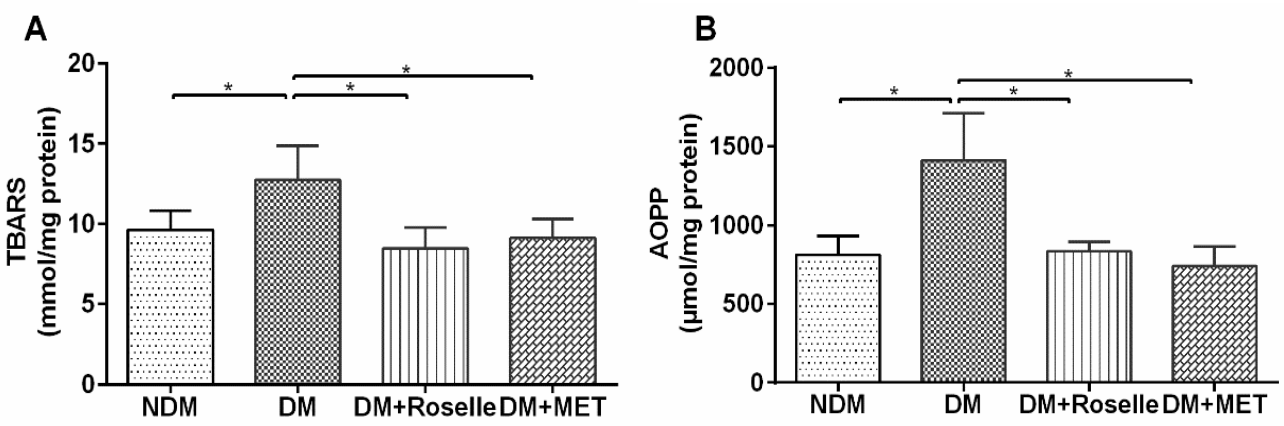

FIGURE 1. Quantitative data for analysis of (A) TBARS and (B) AOPP level in cardiac mitochondrial of experimental rats. *significantly different $(\mathrm{p}<0.05)$ 
promote excretion of lipid in feces, thereby reducing lipid level and accumulation of adipose tissue (CarvajalZarrabal et al. 2009). These compounds could also block lipogenesis (Hansawasdi et al. 2000) and accelerate lipolysis, thus assisting in the treatment of hyperlipidemia (Li et al. 2017).

Diabetes successfully induced cardiac oxidative damage in rats, as shown by marked increment in the level of TBARS and AOPP, accompanied by significant reduction in the status of total SOD, SOD-2, GSH and CAT as shown in Figures 1 and 2. Increment of ROS production that occurred during four weeks of diabetes is explained by the high TBARS and AOPP levels. During hyperglycemia, the electron transport chain of the cardiac mitochondria is disturbed, resulting in leakage of electrons and decoupling of the respiratory chain which leads to high ROS production and subsequently a significant increase in lipid and protein peroxidation (Matough et al. 2012).
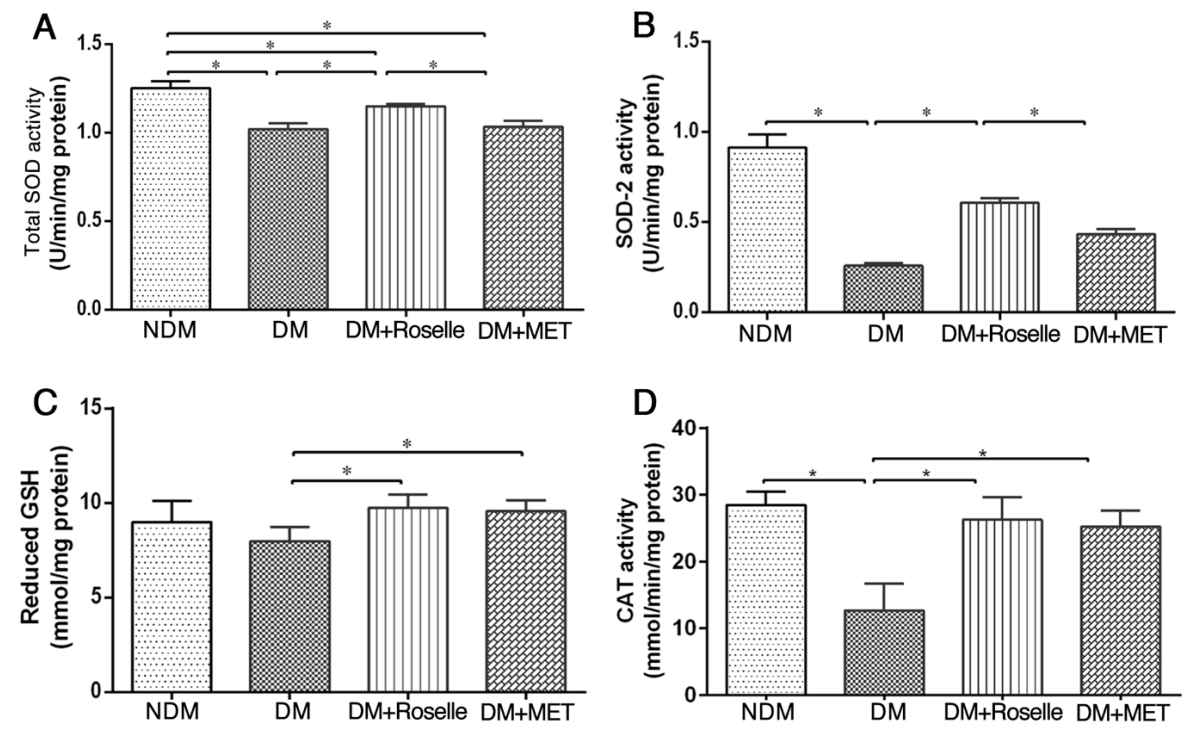

FIGURE 2. Quantitative data for analysis of (A) total SOD activity, (B) SOD-2 activity, (c) reduced glutathione level, and (D) catalase (CAT) activity in cardiac mitochondrial of experimental rats. * significantly different $(\mathrm{p}<0.05)$

Increased oxidative stress and cellular damage caused by hyperglycemia was evident from the disturbances observed in enzymatic activities of total SOD, SOD2, and CAT as well as GSH level in the cardiac tissue of diabetic heart. HPE significantly attenuated these changes. A significant improvement in the antioxidant status was observed in DM+Roselle group as compared to the DM group. According to El-Gendy et al. (2010), this improvement is attributed to the defense mechanism against oxidative stress in the cellular repair process. In addition, Mohammed Yusof et al. (2018a, 2018b) suggested that the increased activities of total SOD and CAT after HPE supplementation allow the heart to regulate rate of lipid and protein oxidation. According to Mannervik et al.
(1988), antioxidants constitute the second line of enzymatic defense, by playing an important role in the detoxification of both endogenous and exogenous toxic compounds, and preventing the formation of lipid peroxidation products (Verma et al. 2007). On the other hand, Metformin-treated diabetic rats showed significantly increased status of total SOD and SOD-2, catalase and GSH in the diabetic rats.

Excessive production of ROS in hyperglycemic condition is accountable for oxidative stress and mitochondrial damage. According to Shen (2010), mitochondrial Complex I (NADH dehydrogenase) and Complex III (ubiquinone-cytochrome c oxidoreductase) are considered as the main sites for the generation of ROS in the mitochondria. Chronic hyperglycemia further promotes the formation of AGEs, which then increases the generation 
of superoxide from mitochondrial Complex I (Coughlan et al. 2009) and leads to cardiac mitochondrial damage. Analysis of Complex I and Complex III activities in freshly prepared isolated mitochondria is presented in Figure 3. Respiratory Complex I activity in the isolated cardiac mitochondria decreased significantly in DM+Roselle group, indicating a reduction of ROS production in cardiac mitochondrial. Myocardial superoxide generation was aggravated in DM group, as shown remarkably higher Complex I activity in cardiac tissue. Despite these, no significant change was observed for Complex III activity in all groups.
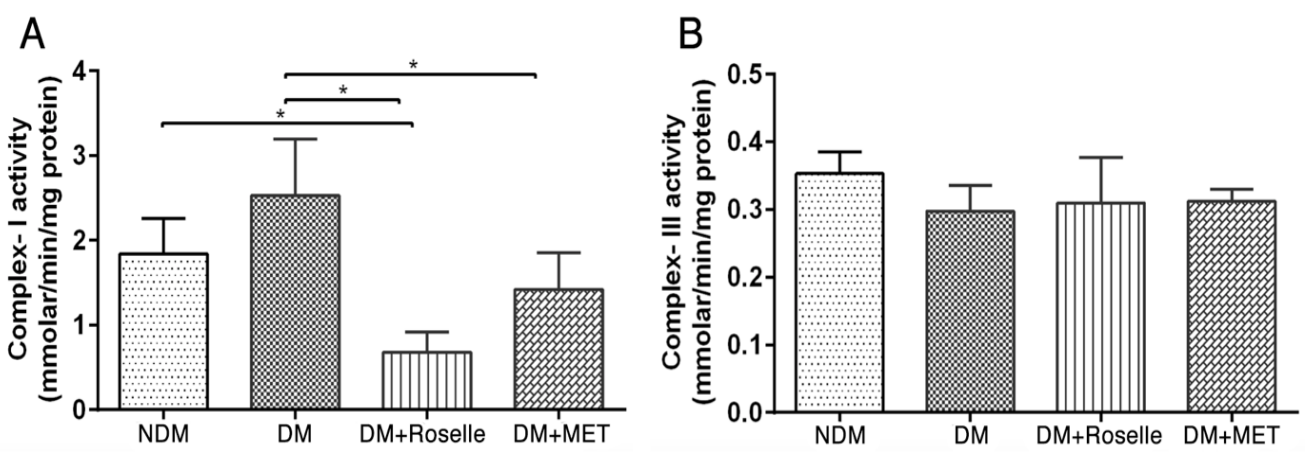

FIGURE 3. Quantitative data for analysis of (A) Complex-1 activity and (B) Complex-III activity of cardiac mitochondrial of experimental rats. * significantly different $(\mathrm{p}<0.05)$

As shown in Figure 4, the appearance and the organization of cardiac mitochondria of untreated diabetic rat were unorganized and more spherical in shape. These findings are consistent with a previous study which reported cardiac damage in diabetes rats was accompanied by the damage of the cristae structure and the increased in mitochondrial size (Mohammed Yusof et al. 2018a). In this current study these morphological changes were significantly reduced by the roselle supplementation.
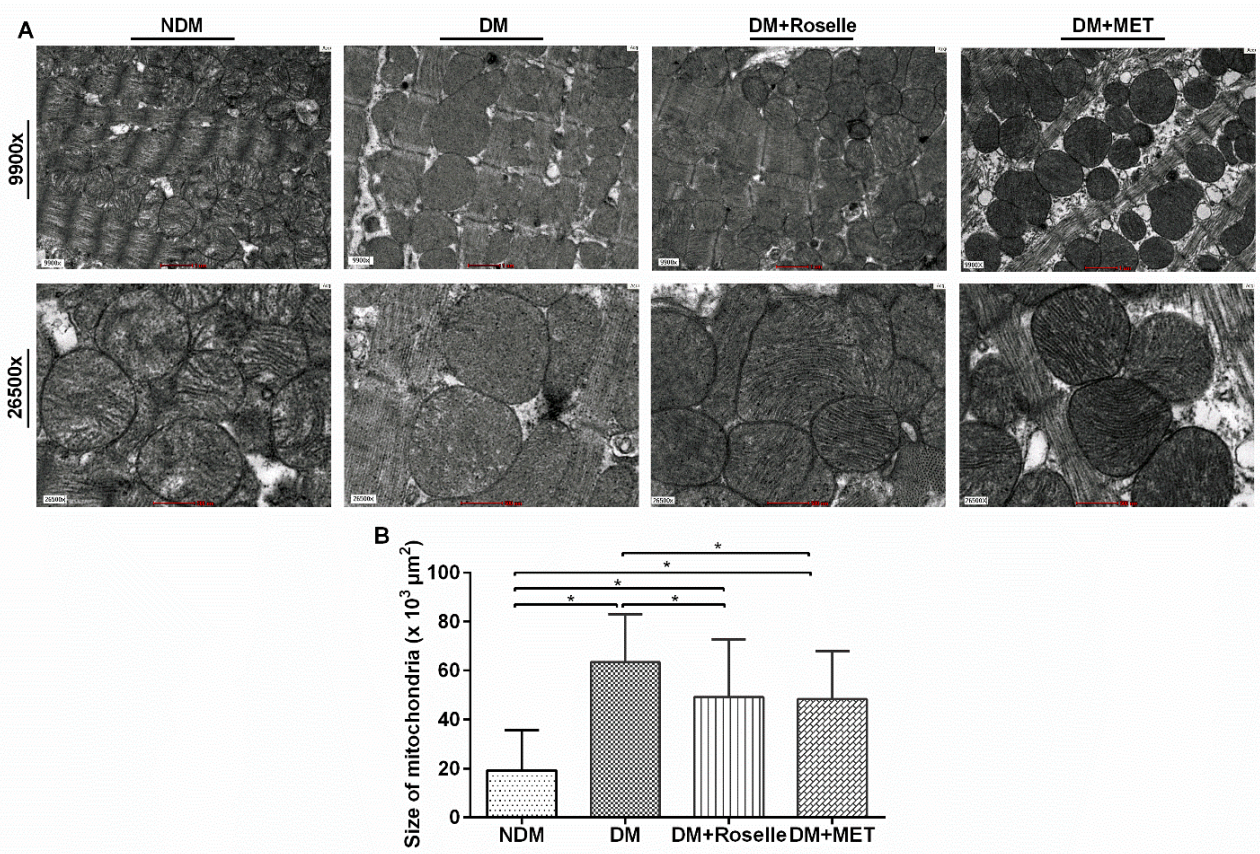

FIGURE 4. (A) Electron microscope micrograph of mitochondria in the hearts of experimental rats and (B) comparison the size of the cardiac mitochondria between experimental groups. *significantly different $(\mathrm{p}<0.05)$ 
Nishikawa et al. (2000) reported that reducing mitochondrial ROS production through the increase in manganese dismutase superoxide activity (MnSOD) or SOD-2 in endothelial cells can inhibit mitochondrial dysfunction caused by hyperglycemia. In addition, increased SOD-2 activity also inhibits ROS production, preventing mitochondrial matrix and membranes injuries and reducing mitochondrial swelling (Shen et al. 2010). Reduced respiratory Complex I activity and elevation of SOD-2 activity after HPE supplementation in this current study supports the evidence that roselle is able to protect the diabetic heart by augmenting mitochondrial antioxidant defense system, hence preventing further mitochondrial dysfunction caused by hyperglycemia.

\section{CONCLUSION}

This study demonstrates the potential effects of HPE in ameliorating oxidative stress and mitochondrial damage in diabetic heart as well as improving dyslipidemia and hyperglycemia condition. Since the pathophysiology of cardiovascular complication in diabetes and its development of complication involve oxidative stress, dyslipidemia, and hyperglycemia, supplementation of HPE may be advantageous in prevention of disease progression and further complications.

\section{ACKNOWLEDGEMENTS}

We gratefully acknowledge the financial support from the Universiti Kebangsaan Malaysia, Malaysia via Geran Universiti Penyelidikan (GUP-2017-040). We would also like to acknowledge Ms Mazlin Aman for her significant contribution in this project.

\section{REFERENCES}

Beyer, W.F. \& Fridovich, I. 1987. Assaying for superoxide dismutase activity: Some large consequences of minor changes in conditions. Analytical Biochemistry 161(2): 559-566.

Brownlee, M. 2001. Biochemistry and molecular cell biology of diabetic complications. Nature 414(6865): 813.

Budin, S.B., Sharifuddin, N.A., Jubaidi, F.F. \& Zainalabidin, S. 2019. The potential of Hibiscus sabdariffa Linn. (roselle) polyphenol-rich extract as a cardioprotective agent in myocardial infarction model. Jurnal Teknologi 81(5): 25-31.

Budin, S.B., Abdul Rahman, W.A., Jubaidi, F.F., Mohammed Yusof, N.L., Taib, I.S. \& Zainalabidin, S. 2018. Roselle (Hibiscus sabdiriffa) polyphenol-rich extract prevents testicular damage of diabetic rats. Journal of Applied Pharmaceutical Science 8(2): 65-70.

Carvajal-Zarrabal, O., Hayward-Jones, P., Orta-Flores, Z., Nolasco-Hipólito, C., Barradas-Dermitz, D., AguilarUscanga, M. \& Pedroza-Hernández, M. 2009. Effect of Hibiscus sabdariffa L. dried calyx ethanol extract on fat absorption-excretion, and body weight implication in rats. BioMed Research International 2009: 394592.
Chen, C.C., Hsu, J.D., Wang, S.F., Chiang, H.C., Yang, M.Y., Kao, E.S., Ho, Y.C. \& Wang, C.J. 2003. Hibiscus sabdariffa extract inhibits the development of atherosclerosis in cholesterol-fed rabbits. Journal of Agricultural and Food Chemistry 51(18): 5472-5477.

Coughlan, M.T., Thorburn, D.R., Penfold, S.A., Laskowski, A., Harcourt, B.E., Sourris, K.C., Tan, A.L., Fukami, K., ThallasBonke, V. \& Nawroth, P.P. 2009. Rage-induced cytosolic ROS promote mitochondrial superoxide generation in diabetes. Journal of the American Society of Nephrology 20(4): 742-752.

Dai, D.F., Johnson, S.C., Villarin, J.J., Chin, M.T., NievesCintrón, M., Chen, T., Marcinek, D.J., Dorn, G.W., Kang, Y.J. \& Prolla, T.A. 2011. Mitochondrial oxidative stress mediates angiotensin ii-induced cardiac hypertrophy and gaq overexpression-induced heart failure. Circulation Research 108(7): 837-846.

El-Gendy, K.S., Aly, N.M., Mahmoud, F.H., Kenawy, A. \& ElSebae, A.K.H. 2010. The role of vitamin C as antioxidant in protection of oxidative stress induced by imidacloprid. Food and Chemical Toxicology 48(1): 215-221.

Ellman, G.L. 1959. Tissue sulfhydryl groups. Archives of Biochemistry and Biophysics 82(1): 70-77.

Gomes, A.P., Price, N.L., Ling, A.J., Moslehi, J.J., Montgomery, M.K., Rajman, L., White, J.P., Teodoro, J.S., Wrann, C.D. \& Hubbard, B.P. 2013. Declining NAD ${ }^{+}$induces a pseudohypoxic state disrupting nuclear-mitochondrial communication during aging. Cell 155(7): 1624-1638.

Hansawasdi, C., Kawabata, J. \& Kasai, T. 2000. A-amylase inhibitors from roselle (Hibiscus sabdariffa Linn.) tea. Bioscience, Biotechnology, and Biochemistry 64(5): 10411043.

Huynh, K., Bernardo, B.C., Mcmullen, J.R. \& Ritchie, R.H. 2014. Diabetic cardiomyopathy: mechanisms and new treatment strategies targeting antioxidant signaling pathways. Pharmacology \& Therapeutics 142(3): 375-415.

Iglesias-González, J., Sánchez-Iglesias, S., Beiras-Iglesias, A., Soto-Otero, R. \& Méndez-Álvarez, E. 2013. A simple method for isolating rat brain mitochondria with high metabolic activity: Effects of EDTA and EGTA. Journal of Neuroscience Methods 213(1): 39-42.

Lee, S.C. \& Pervaiz, S. 2007. Apoptosis in the pathophysiology of diabetes mellitus. The International Journal of Biochemistry \& Cell Biology 39(3): 497-504.

Li, L., Peng, M., Ge, C., Yu, L. \& Ma, H. 2017. (-)-Hydroxycitric acid reduced lipid droplets accumulation via decreasing acetyl-COA supply and accelerating energy metabolism in cultured primary chicken hepatocytes. Cellular Physiology and Biochemistry 43(2): 812-831.

Li, Y.W. \& Aronow, W.S. 2011. Diabetes mellitus and cardiovascular disease. Journal of Clinical and Experimental Cardiology 2(2): 1-9.

Lim, Y.C., Budin, S.B., Othman, F., Latip, J. \& Zainalabidin, S 2017. Roselle polyphenols exert potent negative inotropic effects via modulation of intracellular calcium regulatory channels in isolated rat heart. Cardiovascular Toxicology 17(3): 251-259.

Liu, Q., Wang, S. \& Cai, L. 2014. Diabetic cardiomyopathy and its mechanisms: Role of oxidative stress and damage. Journal of Diabetes Investigation 5(6): 623-634. 
Madsen-Bouterse, S.A., Zhong, Q., Mohammad, G., Ho, Y.S. \& Kowluru, R.A. 2010. Oxidative damage of mitochondrial DNA in diabetes and its protection by manganese superoxide dismutase. Free Radical Research 44(3): 313321.

Mannervik, B., Helena Danielson, U. \& Ketterer, B. 1988. Glutathione transferases - structure and catalytic activity. Critical Reviews in Biochemistry 23(3): 283-337.

Matough, F.A., Budin, S.B., Hamid, Z.A., Alwahaibi, N. \& Mohamed, J. 2012. The role of oxidative stress and antioxidants in diabetic complications. Sultan Qaboos University Medical Journal 12(1): 5-18.

Mohammed Yusof, N.L., Zainalabidin, S., Mohd Fauzi, N. \& Budin, S.B. 2018a. Hibiscus sabdariffa (Roselle) polyphenol-rich extract averts cardiac functional and structural abnormalities in type 1 diabetic rats. Applied Physiology, Nutrition and Metabolism 43(12): 1224-1232.

Mohammed Yusof, N.L., Jubaidi, F.F., Mohamad Nasir, S.N., Yusoff, N.A., Mohd Fauzi, N., Zainalabidin, S. \& Budin, S.B. 2018b. Hibiscus sabdariffa (Roselle) polyphenol-rich extract prevents the aortic oxidative damage in type 1 diabetic rats. Jurnal Teknologi 80(2): 1-8.

Nisoli, E., Falcone, S., Tonello, C., Cozzi, V., Palomba, L., Fiorani, M., Pisconti, A., Brunelli, S., Cardile, A. \& Francolini, M. 2004. Mitochondrial biogenesis by no yields functionally active mitochondria in mammals. Proceedings of the National Academy of Sciences 101(47): 16507-16512.

Ochani, P.C. \& D'mello, P. 2009. Antioxidant and antihyperlipidemic activity of Hibiscus sabdariffa Linn. leaves and calyces extracts in rats. Indian Journal of Experimental Biology 47(4): 276-282.

Packer, M., Pitt, B., Rouleau, J.L., Swedberg, K., Demets, D.L. \& Fisher, L. 2017. Long-term effects of flosequinan on the morbidity and mortality of patients with severe chronic heart failure: Primary results of the profile trial after 24 years. JACC: Heart Failure 5(6): 399-407.

Peng, C.H., Chyau, C.C., Chan, K.C., Chan, T.H., Wang, C.J. \& Huang, C.N. 2011. Hibiscus sabdariffa polyphenolic extract inhibits hyperglycemia, hyperlipidemia, and glycation-oxidative stress while improving insulin resistance. Journal of Agricultural and Food Chemistry 59(18): 99019909.

Shen, G.X. 2010. Oxidative stress and diabetic cardiovascular disorders: Roles of mitochondria and NADPH oxidase. Canadian Journal of Physiology and Pharmacology 88(3): 241-248.

Si, L.Y.N., Ali, S.A.M., Latip, J., Fauzi, N.M., Budin, S.B. \& Zainalabidin, S. 2017a. Roselle is cardioprotective in dietinduced obesity rat model with myocardial infarction. Life Sciences 191: 157-165.

Si, L.Y.N., Kamisah, Y., Ramalingam, A., Lim, Y.C., Budin, S.B. \& Zainalabidin, S. 2017b. Roselle supplementation prevents nicotine-induced vascular endothelial dysfunction and remodelling in rats. Applied Physiology, Nutrition, and Metabolism 42(7): 765-772.

Srivastava, A., Akoh, C.C., Yi, W., Fischer, J. \& Krewer, G. 2007. Effect of storage conditions on the biological activaty of phenolic compounds of blueberry extract packed in glass bottles. Journal of Agricultural and Food Chemistry 55: 2705-2713.

Stocks, J. \& Dormandy, T. 1971. The autoxidation of human red cell lipids induced by hydrogen peroxide. British Journal of Haematology 20(1): 95-111.

Tandler, B. 1990. Improved uranyl acetate staining for electron microscopy. Microscopy Research and Technique 16(1): 81-82.

Vanessa Fiorentino, T., Prioletta, A., Zuo, P. \& Folli, F. 2013. Hyperglycemia-induced oxidative stress and its role in diabetes mellitus related cardiovascular diseases. Current Pharmaceutical Design 19(32): 5695-5703.

Verma, R.S., Mehta, A. \& Srivastava, N. 2007. In vivo chlorpyrifos induced oxidative stress: Attenuation by antioxidant vitamins. Pesticide Biochemistry and Physiology 88(2): 191-196.

Witko-Sarsat, V., Friedlander, M., Capeillère-Blandin, C., Nguyen-Khoa, T., Nguyen, A.T., Zingraff, J., Jungers, P. \& Descamps-Latscha, B. 1996. Advanced oxidation protein products as a novel marker of oxidative stress in uremia. Kidney International 49(5): 1304-1313.

Yusof, N.L.M., Jubaidi, F.F., Nasir, S.N.M., Yusoff, N.A., Fauzi, N.M., Zainalabidin, S. \& Budin, S.B. 2018. Hibiscus sabdariffa (roselle) polyphenol-rich extract prevents the aortic oxidative damage in type 1 diabetic rats. Jurnal Teknologi 80(2): 1-8.

Yusof, N.M., Zainalabidin, S., Fauzi, N.M. \& Budin, S. 2017. Cardioprotective effects of roselle (Hibiscus sabdariffa Linn.) polyphenol-rich extract in streptozotocin-induced diabetic rats. International Journal of Cardiology 249: S4.

Zainalabidin, S., Budin, S.B., Anuar, N.N.M., Yusoff, N.A. \& Yusof, N.L.M. 2018. Hibiscus sabdariffa Linn. improves the aortic damage in diabetic rats by acting as antioxidant. Journal of Applied Pharmaceutical Science 8(01): 108-114.

Nur Liyana Mohammed Yusof, Tengku Nurul Tasnim Tengku Affendi, Fatin Farhana Jubaidi \& Siti Balkis Budin*

Centre for Diagnostic

Therapeutic and Investigative Studies

Faculty of Health Sciences

Universiti Kebangsaan Malaysia

50300 Kuala Lumpur, Federal Territory

Malaysia

Satirah Zainalabidin

Centre for Toxicology and Health Risk Studies

Faculty of Health Sciences

Universiti Kebangsaan Malaysia

50300 Kuala Lumpur, Federal Territory

Malaysia

*Corresponding author; email: balkis@ukm.edu.my

Received: 18 January 2020

Accepted: 18 April 2020 